\title{
KEPRIBADIAN PADA PASIEN PENYALAHGUNAAN NAPZA DI RSJ PROVINSI BALI
}

\author{
Desak Made Ari Dwi Jayanti* \\ *STIKes Wira Medika Bali
}

\begin{abstract}
Penyalahgunaan napza merupakan permasalahan yang menjadi perhatian dunia yang dapat menyebabkan timbulnya berbagai permasalahan diantaranya gangguan somatisasi, kecemasan, skizofrenia, paranoid dan depresi. Penelitian ini bertujuan untuk mengetahui hubungan kepribadian dengan penyalahgunaan napza di RSJ Provinsi Bali. Penelitian ini merupakan deskriptip korelasi dengan pendekatan cross-sectional. Populasi adalah pasien pengguna napza dengan jumlah sampel 39 orang. Pengumpulan data variabel independent menggunakan kuesioner kepribadian yang diadopsi dari Sembiring dan variabel dependent menggunakan Kuesioner WHO-ASSIST V3.0 diadopsi dari World Health Organitation (WHO) dan Draf Pedoman Konseling Gangguan Penggunaan NAPZA Bagi Petugas Kesehatan. Data dianalisis dengan uji Rank Spearman. Hasil penelitian didapatkan p-value lebih kecil dari 0,05 sehingga dapat disimpulkan ada hubungan kepribadian dengan penyalahgunaan napza. Disarankan kepada perawat agar memberikan motivasi kepada pasien penyalahgunaan napza sehingga pasien dengan kepribadian negatif dapat memiliki kepribadian yang positif dan kepada keluarga agar selalu menanamkan konsep diri yang positif sehingga memiliki kepribadian yang positif.
\end{abstract}

Kata Kunci: Kepribadian, Penyalahgunaan Napza

\section{LATAR BELAKANG}

Meningkatnya gobalisasi juga diringi dengan berkembangnya berbagai permasalahan yang terjadi di masyarakat, salah satunya adalah masalah penyalahgunaa NAPZA atau narkoba. Masalah penyalahgunaan narkoba merupakan masalah yang menjadi pusat perhatian di dunia, dimana hampir seperempat miliar penduduk di dunia dalam rentang usia 15-64 tahun diperkirakan menggunakan narkoba pada tahun 2013, sejumlah 27 juta orang $(0,6 \%)$ menderita akibat mengkonsumsi narkoba. Data pada tahun 2012 ditemukan sejumlah 243 juta orang $(5,3 \%)$ dalam rentang usia 15-64 tahun mengkonsumsi narkoba. Data menurur World Drug Report 2014 menunjukkan sejumlah 27 juta orang melakukan penyalahgunaan narkoba dengan ketergantungan (BNN, 2016).

Data tahun 2005 dan 2010 di Indonesia ditemukan prevalensi penyalahgunaan narkoba di tingkat rumahtangga relatif stagnan sekitar 2,4\% dimana satu diantara 42 orang pada usia 10-59 tahun pernah memakai narkoba sekali seumur hidupnya. Tahun 2015, 17 dari 1000 orang penduduk pernah pakai narkoba di tingkat Rumah Tangga Umum. Angka prevalensi lebih besar pada laki-laki, di kota dan tidak bekerja. Angka prevalensi pemakaian narkoba lebih tinggi di rumah tangga khusus dibandingkan dengan rumah tangga umum. Data tahun 2015 menunjukkan Sejumlah $14,5 \%$ pemakai narkoba ditemukan di tempat hiburan, 6,4\% di kampus dan 4,6 \% di pasar. Tempat hiburan sejumlah $16 \%$ perempuan pakai narkoba dimana sejumlah $14 \%$ diantaranya pada kelompok usia 20-29 tahun. Penyalahgunaan narkoba di kampus lebih banyak pada kelompok laki-laki. Data dari sisi pendidikan, prevalensi tertinggi sejumlah $13,4 \%$ pada perempuan tamat SLTP, dimana sejumlah $19,4 \%$ berusia $20-29$ tahun. Sementara itu sejumlah 10,3\% pada laki-laki tamat SLTA dan sejumlah 9,0\% tamat SLTP. Dari sisi pekerjaan, sejumlah $17,6 \%$ laki-laki berstatus tidak bekerja dan sejumlah $13,5 \% \quad$ yang berstatus pelajar/mahasiswa (BNN, 2016).

Data di Indonesia menunjukkan terdapat 12 provinsi dengan angka prevalensi penyalahgunaan narkoba semakin marak yaitu Sumatera Utara, Jambi, DKI Jakarta, Jawa Barat, DI Yogyakarta, Jawa Timur, Bali, Kalimantan Barat, Kalimantan Timur, Sulawesi Selatan, Sulawesi Utara, dan Papua. Alasan pemakaian narkoba pertama kali karena ingin coba-coba yang kemudian 
disusul karena ajakan teman dan bersenangsenang (BNN, 2016).

Data hasil penelitian di Denpasar dan Badung menunjukkan sebesar $34 \%$ remaja beresiko terekpos penyalahgunaan narkoba dimana dari 800 responden itu sejumlah 268 responden mengunjungi klub malam dengan frekuensi satu kali dalam seminggu (77\%) dan 2-7 kali dalam seminggu (23\%) (Sugitha et al., 2012)

Terdapat berbagai faktor penyebab penyalahgunaan napza salah satu diantaranya adalah tipe kepribadian. Kepribadian merupakan perilaku, perasaan dan pola pikir yang telah mendarah daging. Kepribadian akan memiliki peran dalam penyalah gunaan ini, dimana lebih cenderung terjadi pada remaja karena remaja yang menjadi pecandu akan cendrung memiliki kepribadian yang negatif dan harga diri yang rendah (Stuart, 2016). Hawari menyatakan ciri kepribadian menjadi salah satu faktor yang mempengaruhi penyalahgunaan napza biasanya pada orang dengan ciri kepribadian yang lemah dan antisosial dengan gejala mudah kecewa, kurangkuat menghadapi kegagalan, tidak sabar, kurang mandiri, kurang percaya diri dan ingin selalu mendapat pengakuan, sedangkan ciri kepribadian antisosial ditandai dengan perilaku suka agresif, suka menentang peraturan dan suka membrontak (Afiatin, 1998).

Data hasil penelitian oleh Reza menunjukkan bahwa tipe kepribadian the big five memiliki korelasi yang sinifikan terhadap penyesuaian diri pada anak didik di lapas (Reza, 2017). Widiantari dan Herdiyanto menyatakan terdapat perbedaan intensitas komunikasi melalui jejaring sosial pada tipe kepribadian introvert dengan ekstrovert dimana tipe kepribadian ekstrovert memiliki intensitas yang tinggi dibanding tipe kepribadian introvert (Widiantari dan Herdiyanto, 2013). Ada berbagai dampak permasalahan yang akan muncul akibat penyalah gunaan napza diantaranya adalah gangguan somatisasi, kecemasan, skizofrenia, paranoid dan depresi (Indiyah, 2005).

Data berdasarkan rekammedis Rumah Sakit Jiwa Provinsi Bali ditemukan pada tahun 2015 sejumlah 51 orang dengan penyalahgunaan napza dan tahun 2016 meningkat menjadi 195 orang dimana diantaranya 78 orang menjalani rawat jalan di poli napsza, 86 orang rawat inap dan 31 orang menjalani pasca rawat (Rekam Medis RSJ Provinsi Bali, 2016).

\section{METODE}

Jenis penelitian ini adalah deskriptip korelasi dengan pendekatan cross-sectional. Penelitian dilaksanakan di RSJ Provinsi Bali karena telah ada ruang rehabilitasi dan poliklinik penyalahgunaan napza serta bekerjasama dengan BNN Provinsi Bali.

Populasi dalam penelitian ini adalah semua pasien penyalahgunaan napza di RSJ Provinsi Bali dengan jumlah sampel sejumlah 39 orang dengan tekhnik pengambilan sampel jenuh. Alat ukur yang digunakan adalah kuesioner. Variabel independent menggunakan kuesioner kepribadian yang diadopsi dari Sembiring (2014) dan variabel dependent menggunakan Kuesioner WHO-ASSIST V3.0 diadopsi dari World Health Organitation (WHO) dan Draf Pedoman Konseling Gangguan Penggunaan NAPZA Bagi Petugas Kesehatan.

Data penelitian diolah dan analisis menggunkan uji Spearman Rank untuk mengetahui ada dan tidaknya hubungan amtara kepribadian dengan penyalahgunaan napza.

\section{HASIL}

\section{Analisis Univariat}

Karakteristik responden pada penelitian ini sebagian besar berusia dewasa awal sejumlah 17 orang $(43,6 \%)$, berpendidikan tingkat SMA sejumlah 21 orang $(53,8 \%)$ dan berjenis kelamin laki-laki sejumlah 37 orang $(95 \%)$. 
Tabel 1: Distribusi Responden Berdasarkan Kepribadian

\begin{tabular}{lcc}
\hline \multicolumn{1}{c}{ Kepribadian } & $\mathrm{f}$ & $\%$ \\
\hline Positif (0) & 13 & 33,3 \\
\hline Negatif (1-5) & 26 & 66,7 \\
\hline Jumlah & 39 & 100 \\
\hline
\end{tabular}

Berdasarkan tabel di atas terbanyak dengan kepribadian negatif sejumlah 26 orang $(66,7 \%)$.

Tabel 2: Distribusi Responden Berdasarkan Penyalahgunaan Napza

\begin{tabular}{lcc}
\hline \multicolumn{1}{c}{ Penyalahgunaan Napza } & $\mathrm{f}$ & $\%$ \\
\hline Resiko Sedang & 20 & 51,3 \\
\hline Resiko Tinggi & 19 & 48,7 \\
\hline Jumlah & 39 & 100 \\
\hline
\end{tabular}

Berdasarkan tabel di atas menunjukkan penyalahgunaan napza tertinggi dengan resiko sedang sejumlah 20 orang $(51,3 \%)$.

\section{Analisis Bivariat}

Tabel 3: Distribusi Hubungan Kepribadian dengan Penyalahgunaan Napza

\begin{tabular}{|c|c|c|c|c|c|c|c|}
\hline \multirow{3}{*}{ Kepribadian } & \multicolumn{4}{|c|}{$\begin{array}{c}\text { Penyalahgunaan } \\
\text { Napza }\end{array}$} & \multirow{2}{*}{\multicolumn{2}{|c|}{ Total }} & \multirow[b]{2}{*}{$p$} \\
\hline & \multicolumn{2}{|c|}{$\begin{array}{l}\text { Resiko } \\
\text { Sedang }\end{array}$} & \multicolumn{2}{|c|}{$\begin{array}{l}\text { Resiko } \\
\text { Tinggi }\end{array}$} & & & \\
\hline & $\mathrm{f}$ & $\%$ & $\mathrm{f}$ & $\%$ & $\mathrm{f}$ & $\%$ & \\
\hline Negatif & 10 & 25,6 & 16 & 41 & 26 & 66,7 & 023 \\
\hline Positif & 10 & 25,6 & 3 & 7,7 & 13 & 33,3 &, $0<3$ \\
\hline Jumlah & 20 & 51,3 & 19 & 48,7 & 39 & 100 & \\
\hline
\end{tabular}

Berdasarkan tabel di atas dari total 26 orang dengan kepribadian negatif, terdapat 10 orang dengan resiko sedang melakukan penyalahgunaan napza dan 16 orang dengan resiko tinggi melakukan penyalahgunaan napza, sedangkan dari total 13 orang denga tipe kepribadian positif terdapat 10 orang resiko sedang melakukan penyalahgunaan napza dan 3 orang resiko tinggi melakukan penyalahgunaan napza. Hasil uji Rank Spearman didapatkan $p$-value lebih kecil dari 0,05 sehingga dapat disimpulkan ada hubungan kepribadian dengan penyalahgunaan napza di RSJ Provinsi Bali.

\section{PEMBAHASAN}

\section{Kepribadian}

Kepribadian adalah perasaan dan perilaku yang telah melekat pada diri seseorang (Stuart, 2016). Data ini didukung oleh pernyataan Hawari dalam Afiatin (1998) dimana kepribadian yang lemah dan antisosial dapat menjadi salah satu penyebab penyalahgunaan napza, dimana kepribadian lemah dan antisosial merupakan kepribadian yang negatif.

Hasil penelitian menurut Idiyah (2005) menunjukkan terjadinya penyalah gunaan napza diakibatkan karena adanya beban batin dimana $76 \%$ karena merasa dikucilkan masyarakat, $51 \%$ menyatakan tidak kuat menanggung penderitaan dan $60 \%$ menyatakan tidak kuat melepaskan diri dari penderitaan. Data tersebut menunjukkan orang yang memiliki kepribadian yang lemah. Peneliti berpendapat orang dengan kepribadian negatif akan cenderung melakukan hal negatif seperti penyalah gunaan narkoba dimana mereka akan mudah untuk dipengaruhi oleh orang lain.

\section{Penyalahgunaan Napza}

Penyalahgunaan napza (narkotika, psikotropika, dan zat adiktif) merupakan suatu masalah yang dapat menghancurkan generasi muda dimana dapat mengakibatkan kecanduan dan gangguan klinis maupun gangguan sosial dan apabila penggunaannya dihentikan maka akan menimbulkan perasaan gelisah, cemas depresi dan yanglainnya (Ricardo, 2010).

Hasil penelitian oleh Nafikandini et al (2014) yang dilakukan dengan metode studi kualitatif menunjukkan bahwa penyalahgunaan napza dilakukan oleh subjek sejak bangku SMP dimana mereka menggunakan bahasa-bahasa klusus dalah penggunaan napza sehingga orang lain tidak dapat memahaminya. Sebelum melakukan penyalahgunaan napza subjek memiliki konsep diri yang positif namun setelah menggunakan napza subjek menjadi memiliki konsep diri yang negatif dimana ketika tidak menggunkan napza mereka akan merasa tidak percaya diri dan hidup mereka sebenarnya lebih baik sebelum menggunakan 
napza dari pada setelah menggunakan napza. Keluarga tidak mengetahui kalau responden menggunakan napza namun pacarnya mengetahui kalau responden menggunakan napza. Data hasil penelitian ini juga di dukung oleh penelitian lain dimana $34 \%$ responden beresiko terekpose penyalahgunaan napza karena mereka mengunjungi klub malam (Sugitha et al., 2012).

Hasil penelitian lainnya pada siswa smu negeri di bekasi menunjukkan sebagian besar tingkat penyalahgunaan napza pada kategori kurang sejumlah $28,8 \%$, dimana dari total 386 orang siswa sejumlah 65 orang melakukan penyalahgunaan napza dan dari 65 orang tersebut sejumlah 44 orang pada kategori kurang (Raharni et al., 2006).

\section{Hubungan Kepribadian dengan Penyalahgunaan Napza}

Penyalahgunaan narkoba yang sudah menjadi permasalahan dunia yang menyebabkan berbagai permasalahan baik dari segi ekonomi, medis, sosial dan keamanan bahkan dapat menyebabkan hilangnya generasi bangsa (Indrawati, 2008).

Hasil penelitian menurut Rahmadona dan Agustin (2014) menyatakan terdapat hubungan antara perilaku religius dengan penyalahgunaan narkoba. Terdapat hubungan antara teman sebaya terhadap penyalahgunaan narkoba dan terdapat hubungan antara peran keluarga dengan penyalahgunaan narkoba. Karakteristik responden dalam penelitian ini menunjukkan terbanyak berjenis kelamin laki-laki sejumlah 94,9\%, hasil penelitian ini sejalan dengan penelitian terkait menurut Rahmadona dan Agustin (2014) bahwa sebagian besar responden yang melakukan penyalahgunaan narkoba berjenis kelamin laki-laki sejumlah $81,9 \%$. Data ini menunjukkan laki-laki memiliki potensi lebih besar melakukan penyalahgunaan narkoba.

Berdasarkan tingkat pendidikan data dalam penelitian ini terbanyak dilakukan oleh responden dengan pendidikan SMA sejumlah $53,8 \%$ yang kemudian disusul oleh tingkat pendidikan diploma / PT 30,8\%. Berbeda dengan penelitian yang dilakukan Miratulhusda et al (2015) menunjukkan bahwa karakteristik responden penyalahgunaan obat berdasarkan pendidikan terbanyak dilakukan dengan pendidikan SMP $(36,8 \%)$ dan SD (34,2\%). Rendahnya tingkat pendidikan menunjukkan kurangnya pengetahuan sehingga menjadi penyebab penyalahgunaan obat. Adanya perbedaan ini menunjukkan bahwa penyalahgunaan obat/ napza tidak mutlak karena pendidikan tetapi dapat juga karena faktor lain seperti lingkungan, kepribadian dan yang lainnya.

Hasil penelitian ini didukung oleh penelitian lain dilihat dari karakteristik responden penyalahgunaan narkoba terbanyak dilakukan dengan pendidikan SMA sebanyak 56,2\% (Taheri et al, 2016). Hasil study kualitatif menurut Simangunsong (2015) yang dilakukan pada 12 informan menunjukkan hasil bahwa kepribadian dapat menjadi penyebab penyalahgunaan narkoba dimana informan merupakan remaja yang masih memiliki kepribadian yang labil sehingga mudah terpengaruh oleh temannya untuk mengkonsumsi narkoba.

Hasil penelitian ini didukung oleh pernyataan menurut Stuart (2016) bahwa kepribadian dapat menjadi faktor penyalahgunaaan napza yang lebih cenderung terjadi pada orang dengan kepribadian negatif dan dengan harga diri yang rendah. Peneliti berpendapat perlulah untuk memiliki kepribadian yang positif sehingga akan memiliki konsep diri yang positif dan dapat menghindarkan diri dari hal yang negatif seperti penyalahgunaan narkoba/ napza. Konsep diri yang positif perlu diajarkan sejak dini mulai dari keluarga sehingga bangsa akan memiliki generasi dengan konsep diri yang positif dan kepribadian yang positif pula.

\section{KESIMPULAN}

Sebagian besar responden dalam penelitian ini memiliki kepribadian negatif dengan tingkat penyalahgunaan napza pada resiko sedang. Disimpulkan pula bahwa ada hubungan antara kepribadian dengan penyalahgunaan napza. 
Kesimpulan tersebut menyarankan kepada perawat agar memberikan motivasi kepada pasien penyalahgunaan napza sehingga pasien dengan kepribadian negatif dapat memiliki kepribadian yang positif dan kepada keluarga agar selalu menanamkan konsep diri yang positif sehingga memiliki kepribadian yang positif.

\section{DAFTAR PUSTAKA}

Afiatin. (1998). Bagaimana Menghindarkan Diri Dari Penyalahgunaan Napza. Buletin Psikologi, 6(2.

Badan Narkotika Nasional. (2016). Data Call Center, SMS Center BNN dan Website BNN Tahun 2015. BNN: Jakarta.

Indiyah. (2005). Faktor-Faktor Penyebab Penyalahgunaan Napza: Studi Kasus Pada Narapidana Di Lp Klas Ii/A Wirogunan Yogyakarta. Jurnal Kriminologi Indonesia. 4(1): 87 - 104.

Indrawati, L. (2008). Analisis Proses Internal Bidang Rehabilitasi Medik. [Thesis]. Depok: Pasca Sarjana Universitas Indonesia.

Miratulhusda,W.N., Cahaya, N, dan Fadilaturrahmah. (2015). Studi Retrospektif Penyalahgunaan Obat Pada Pasien Ketergantungan Obat Di Rumah Sakit Jiwa Sambang Lihum. Media Farmasi. 12(2): 247-264.

Reza, A.M. (2017). Pengaruh Tipe Kepribadian Dan Harapan Terhadap Penyesuaian Diri Anak Didik Pemasyarakatan. Jurnal Psikologi Insight Departemen Psikologi. 1(1): 66-81.

Rahmadona dan Agustin. (2014). Faktor Yang Berhubungan Dengan Penyalahgunaan Narkoba Di RSJ Prof. Hb. Sa'anin. Jurnal Kesehatan Masyarakat Andalas. 8(2): 60-66.
Ricardo P. (2010). Upaya Penaggulangan Penyalahgunaan Narkoba Oleh Kepolisian (Studi Kasus Satuan Narkoba Polres Metro Bekasi). Jurnal Kriminologi Indonesia. 6(3): 232-245.

Raharni, Nuning \& Evie. (2006). FaktorFaktor Yang Berhubungan Dengan Penyalahgunaan Napza Pada Slswa Smun Kota Bekasi. Buletin Penelitian Sistem Kesehatan. 9(3): 147-155.

Sugitha, Wirajana \& Wirasuta. (2012). Studi Tingkat Penyalahgunaan Narkoba Pada Mahasiswa di Denpasar dan Badung. Indonesian Journal of Legal and Forensic Sciences. 2(2): 24-26.

Sembiring, N. F. (2014). Faktor-Faktor Penyalahgunaan Narkoba pada Remaja di Lingkungan XIV Keluarahan Glugur Kota Kecamatan Medan Barat. Skripsi. Fakultas Keperawatan Universitas Sumatera Utara.

Simangunsong. (2015). Penyalahgunaan Narkoba Di Kalangan Remaja (Studi kasus pada Badan Narkotika Nasional Kota Tanjungpinang. Jurnal Umrah.

Stuart, G. W. 2016. Prinsip dan Praktik Keperawatan Kesehatan Jiwa Stuart.Buku 2. Jakarta: Elsevier.

Taheri, Z. Amiri, M. Hosseini, M. Mohsenpour, M. Davidson, P.M. (2016). Factors Affecting Tendency for Drug Abuse in People Attending Addiction Treatment Centres: A Quantitative Content Analysis. Journal of Addiction Research \& Therapy 7(2).

Widiantari dan Herdiyanto. (2013). Perbedaan Intensitas Komunikasi Melalui Jejaring Sosial antara Tipe Kepribadian Ekstrovert dan Introvert pada Remaja. Jurnal Psikologi Udayana. 1(1) 106-115. 